\title{
Trade-off between fast growth and the ossification process in common carp (Cyprinus carpio)
}

\author{
Snježana Kužir ${ }^{1 *}$, Krešimir Drašner ${ }^{2}$, Krešimir Matanović ${ }^{3}$ Lucija Bastiančić1, \\ Ivan Vlahek ${ }^{4}$, Serena Savoca ${ }^{5}$, and Emil Gjurčevićc ${ }^{3}$ \\ ${ }^{1}$ Department of Anatomy, Histology and Embryology, Faculty of Veterinary Medicine, University of Zagreb, \\ Zagreb, Croatia \\ ${ }^{2}$ Fish Farm IHOR PARK, Jastrebarsko, Croatia \\ ${ }^{3}$ Department for Biology and Pathology of Fish and Bees, Faculty of Veterinary Medicine, University of Zagreb, \\ Zagreb, Croatia \\ ${ }^{4}$ Department of Animal Breeding and Livestock Production, Faculty of Veterinary Medicine, University of Zagreb, \\ Zagreb, Croatia \\ ${ }^{5}$ Department of Chemical, Biological, Pharmaceutical and Environmental Sciences, University of Messina, \\ Messina, Italy
}

KUŽIR, S., K. DRAŠNER, K. MATANOVIĆ, L. BASTIANČIĆ, I. VLAHEK, S. SAVOCA, E. GJURČEVIĆ: Trade-off between fast growth and the ossification process in common carp (Cyprinus carpio). Vet. arhiv 90 , 485-492, 2020.

\section{ABSTRACT}

The relationship between growth rate and ossification is not consistent among fish. In some species, fast-growing individuals ossify earlier, while in other species, a trade-off between growth rate and ossification exists. This research was conducted to test the hypothesis about the existence of a trade-off mechanism in common carp offspring. For this purpose, specimens from two groups of common carp offspring (96 in total) with different growth rates were sampled at multiple time points between 5 and 29 days post-hatching. The standard length was measured and presented in correlation with the days post-hatching. To evaluate the skeletal system development, whole specimens were fixed in $10 \%$ neutral buffered formalin and stained for bone and cartilage. Particular emphasis was placed on the onset of ossification in the clearly visible bones of the head, vertebral column, and fins. According to our findings, larger, fastgrowing specimens ossify earlier. The hypothesis on the existence of a trade-off between fast growth and the onset of ossification in common carp was not confirmed in our study.

Key words: trade-off; fast growth; ossification; common carp

\section{Introduction}

Growth rate, body weight and disease resistance are important criteria for selection programs in aquaculture (HULATA, 1995). Scientists are

concerned that rapid growth could have different fund costs, e.g. reduced swimming performance (GREGORY and WOOD, 1988; LI et al. 2007;

\footnotetext{
*Corresponding author:

Assoc. Prof. Snježana Kužir, Department of Anatomy, Histology and Embryology, Faculty of Veterinary Medicine, University of Zagreb, Heinzelova 55, 10000, Zagreb, Croatia, Phone: +385 12390 248; Fax: +385 12441 390; E-mail: kuzir@vef.hr
} 
REINBOLD et al., 2009), delay in the onset of the ossification process (ARENDT and WILSON, 2000) or the development of skeletal pathology (HALVER et al., 1969; BAEVERFJORD et al., 1998; REIMER et al., 2017). Furthermore, a delay in the onset of ossification could have a negative influence on the digestive and respiratory system (ARENDT and WILSON, 2000; BERALDO et al., 2003).

The relationship between growth rate and ossification is not consistent in fish (KAVANAGH and ALFORD, 2003; BURDI, 2010; DESCHAMPS and SIRE, 2010). For instance, ARENDT and WILSON (2000) reported the potential cost of rapid growth in two populations of pumpkinseed (Lepomis gibbosus). The authors pointed out that the fish from the fast-growing population showed an average delay of 2 days in the onset of cranial bone ossification. Furthermore, they suggested that "such a delay in ossification may have fitness effects through feeding ability, swimming ability and (or) defense against predators". However, opposite results were obtained in the study by KUŽIR et al. (2018) on the relationship of body size and osteological development in two common carp strains, Poljana mirror carp (PMC) and Poljana scaly carp (PSC). The authors stated that juveniles of PMC, at the same point of sampling $(4,15,17$, 19, 22, 24, and 26-days post-hatching (DPH)), achieved greater mass and length than juveniles of PSC. The osteological development had the same pattern in both groups, but with a delay in PSC. In conclusion, the authors deny any trade-off between fast growth and the ossification process in the common carp strains studied.

This study will present data about the onset of ossification in correlation to body size at certain ontogenetic points in cultured common carp. The main goal of this research is to test the hypothesis on the existence of a trade-off mechanism between the ossification process and growth at the intraspecific level. The long-term purpose of the current study is to give an insight into the ontogenetic development of common carp, which can be useful for carp aquaculture.

\section{Materials and methods}

The research was conducted at a fish farm in Croatia during a regular carp breeding program, as a part of non-experimental clinical veterinary practice. For the purpose of artificial propagation, two females, marked "S" and "C", were selected and hand stripped to obtain eggs. The fertilization of eggs was performed in separate plastic bowls using mixed milt from two males. The fertilized eggs were incubated in separate incubation jars until they hatched. For the first five days, the larvae were kept in separate larvae containers and then stocked in two small nursery ponds (2 ha each) at a rate of 330,000/ha. Feeding of fry in the nursery ponds was based on natural food, while additional feed was introduced from $9^{\text {th }} \mathrm{DPH}$ (50\% fish meal, $50 \%$ wheat flour, enriched with vitamin and mineral mixtures). Offspring from both groups (S and $\mathrm{C}$ ) were sampled at multiple time points, starting from day 5 after hatching. The first sample was taken on the $5^{\text {th }} \mathrm{DPH}$, on the day of stocking in the nursery ponds. Further sampling was conducted at 17, 22, 24, 26, and $29 \mathrm{DPH}$. Every sample contained 8 randomly selected specimens. After sampling and before taking measurements, the fish were euthanized by immersion in a buffered solution of MS-222 (Sigma-Aldrich, St. Louis, MO, USA). Standard length (SL) was measured and used for correlation with DPH. SL was measured from the most anterior part of the head to the posterior edge of hypural elements (ROJO, 1991). Statistical analysis was performed in STATISTICA v.13.5 (Statistica, Inc., 2018). For both groups, the mean and standard deviation (SD) was calculated. Differences between groups were analyzed with Mann - Whitney U test, with a significance level of $\mathrm{P}<0.05$. To evaluate the skeletal system development, whole specimens were fixed in 10\% neutral buffered formalin and stained for bone and cartilage, according to DINGERKUS and UHLER (1977). This double staining method allowed simultaneous detection of cartilaginous elements (alcian blue) as well as calcified structures (alizarin red). Stained specimens were visualized and photographed under an Olympus SZX7 stereoscopic microscope. Clearly visible bony elements and the onset of ossification process was described for the frontal, parietal, supraoccipital, 
parasphenoid, basisphenoid, basioccipital, premaxillary, maxillary, dentary, articular, quadrate, hyomandibular and ceratohyal bones, the opercle, cleithrum, abdominal and caudal vertebrae, and the dorsal, caudal, anal, pelvic and pectoral fins. The study was approved by the Institutional Ethics Committee (Faculty of Veterinary Medicine, University of Zagreb).

\section{Results}

A total of 96 specimens were examined. The mean and standard deviation of body length for both groups are shown in Table 1, while the correlation of the standard length with days post-hatching is presented in Fig. 1.

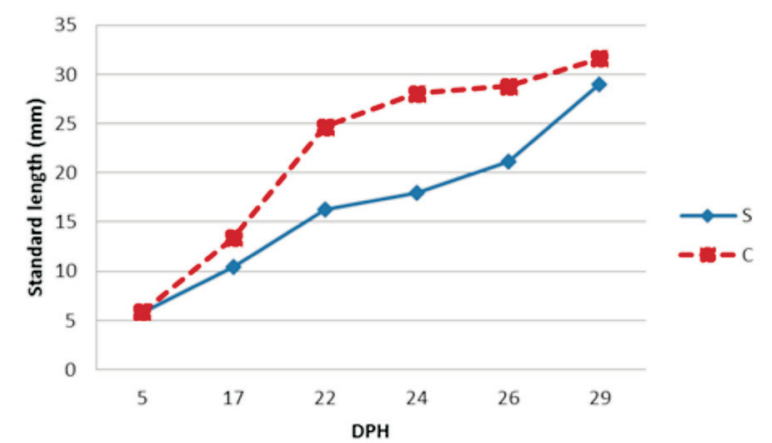

Fig. 1. Standard length (mm) of common carp offspring at the sampling time points (DPH)
In group $\mathrm{S}$ the larvae were $5.80 \pm 0.31 \mathrm{~mm} \mathrm{SL}$ at $5 \mathrm{DPH}$ and there was no sign of the onset of ossification (Fig. 2).

The ossification process is visible in some head bones (parasphenoid, basisphenoid, ceratohyal, cleithrum) at $17 \mathrm{DPH}(\mathrm{SL} 10.49 * * \pm 0.48 \mathrm{~mm})$. At that stage, the very beginning of ossification is visible on the outer edges of the first 8 abdominal vertebrae (Fig. 3a). At 22 DPH (SL 16.24** \pm $1.67 \mathrm{~mm}$ ) ossification started in the basioccipital, premaxillary, maxillary, dentary, articular, quadrate, and hyomandibular bones as well as the opercle. At this stage, ossification was also noticed in the caudal vertebrae, especially in the last four, where the bodies were fully ossified. At the same stage, the onset of ossification is visible in the hypural bones of the caudal fin. At 24 DPH (SL 17.98** $\pm 2.23 \mathrm{~mm}$ ), ossification is also visible in the dorsal fin, while at $26 \mathrm{DPH}$ (SL 21.11** \pm 4.15 $\mathrm{mm}$ ) ossification had started in the anal, pelvic and pectoral fins. At $29 \mathrm{DPH}\left(\mathrm{SL} 28.98^{*} \pm 2.27 \mathrm{~mm}\right)$, and three bones on the head, the frontal, parietal and supraoccipital, had started to ossify. The process of ossification was either evolving or completed on the other investigated elements, except for the fins where ossification was still not complete.

Table 1. Total number, mean and standard deviation of body length (SL) in mm for S and C group

\begin{tabular}{|l|c|c|c|c|c|c|c|}
\hline & & \multicolumn{5}{|c|}{ SL (Mean \pm SD) } \\
\cline { 3 - 8 } Group & $\mathrm{N}$ & $5 \mathrm{DPH}$ & $17 \mathrm{DPH}$ & $22 \mathrm{DPH}$ & $24 \mathrm{DPH}$ & $26 \mathrm{DPH}$ & $29 \mathrm{DPH}$ \\
\hline $\mathrm{S}$ & 8 & $5.80 \pm 0.31$ & $10.49^{* *} \pm 0.48$ & $16.24^{* *} \pm 1.67$ & $17.98^{* *} \pm 2.23$ & $21.11^{* *} \pm 4.15$ & $28.98^{*} \pm 2.27$ \\
\hline $\mathrm{C}$ & 8 & $5.87 \pm 0.28$ & $13.39^{* *} \pm 0.44$ & $24.67^{* *} \pm 1.02$ & $28.06^{* *} \pm 2.00$ & $28.81^{* *} \pm 2.10$ & $31.85^{*} \pm 1.55$ \\
\hline
\end{tabular}

$*$,** Values in the same column are significantly different, $*(\mathrm{P}<0.05), * *(\mathrm{P}<0.01)$.

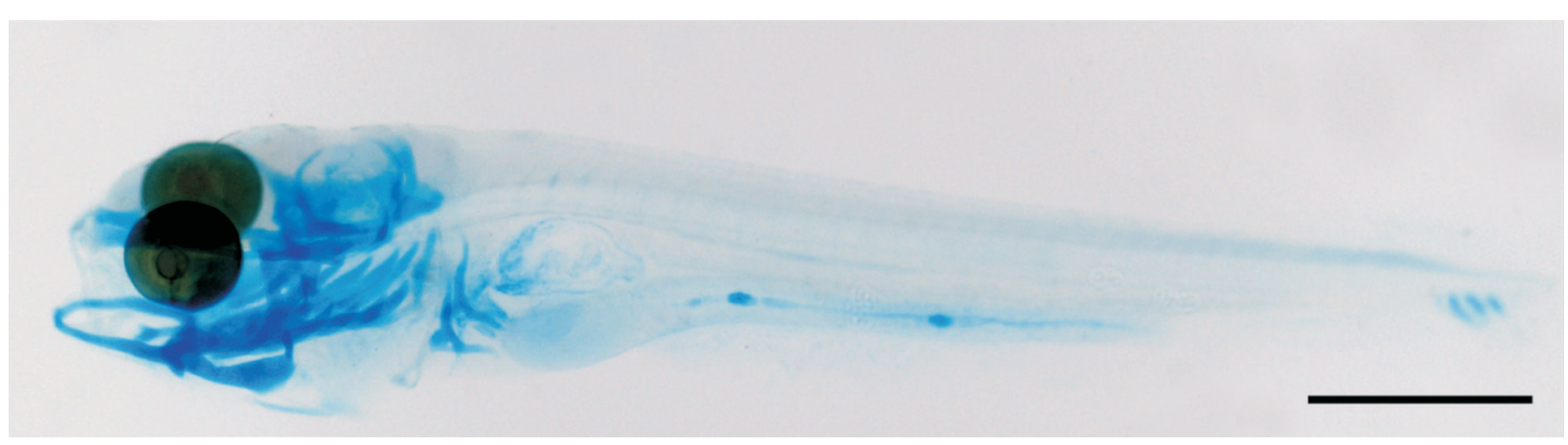

Fig. 2. Five DPH old larva from group S. The existing skeleton is composed of cartilage. Scale bar $=1 \mathrm{~mm}$. 

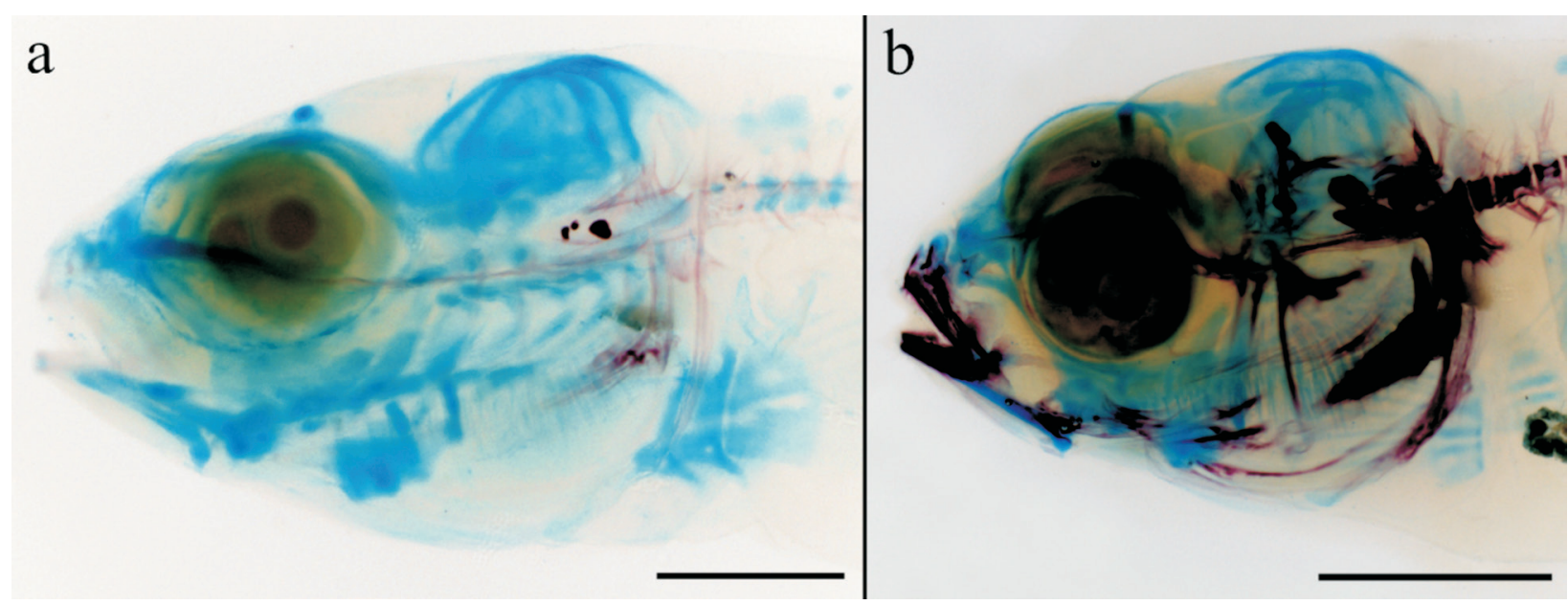

Fig. 3a and 3b. 17 DPH, specimens from group S. The ossification process is visible on the parasphenoid, basisphenoid, ceratohyal and cleithrum and on the outer edges of the first 8 abdominal vertebrae. Scale bar $=1 \mathrm{~mm}$.
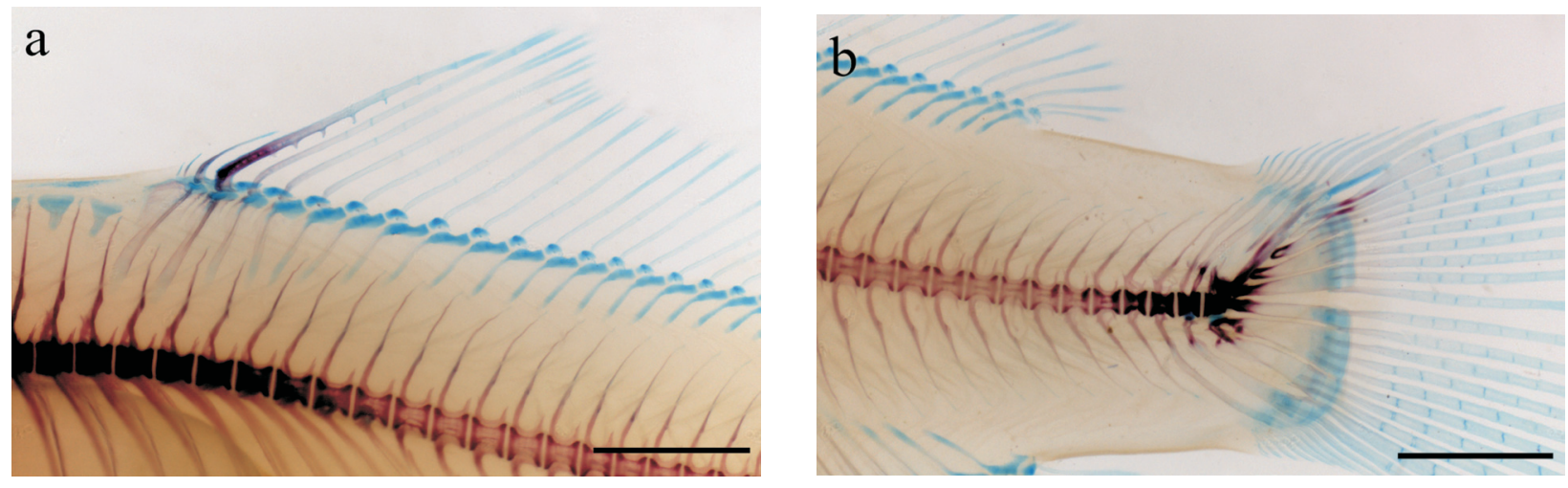

Fig. 4a and 4b. 22 DPH, specimens from group C. The first sign of ossification was noticed in the dorsal and caudal fins. Scale bar $=2 \mathrm{~mm}$.

The ossification process is visible in some head bones (parasphenoid, basisphenoid, ceratohyal and cleithrum) at $17 \mathrm{DPH}$ (SL 10.49** $\pm 0.48 \mathrm{~mm}$ ). At that stage, the very beginning of ossification is visible on the outer edges of the first 8 abdominal vertebrae.

In group C at $5 \mathrm{DPH}$ the larvae were $5.87 \pm 0.28$ $\mathrm{mm}$ SL and there was no sign of ossification. The ossification process is visible in most of the head bones (parasphenoid, basisphenoid, basioccipital, premaxillary, maxillary, dentary, hyomandibular, ceratohyal, opercle, and cleithrum) at $17 \mathrm{DPH}$ (SL 13.39** $\pm 0.44 \mathrm{~mm}$ ) (Fig. 3b). At this stage, ossification is also visible in the abdominal and caudal vertebrae. At 22 DPH (SL 24.67** \pm 1.02 $\mathrm{mm})$, ossification had started in the supraoccipital, articular and quadrate bones. The first sign of ossification was noticed in the dorsal and caudal fins (Fig. 4a and 4b). At 24 DPH (SL 28.06** \pm $2.00 \mathrm{~mm}$ ), a new sign of ossification is visible in the head, the frontal and parietal bones, as well as in the anal, pelvic and pectoral fins. Ossification was in progress or completed by $26 \mathrm{DPH}$, (SL was $28.81^{* *} \pm 2.10 \mathrm{~mm}$ ) in all investigated elements of the head and vertebral column. At $29 \mathrm{DPH}$, (SL $31.85^{*} \pm 1.55 \mathrm{~mm}$ ) ossification had finished in the anal fin while the other fins still had cartilaginous parts.

The oneset of ossification per day post-hatching for both groups is shown in Fig. 5. 
S. Kužir et al.: Growth and ossification in common carp

\begin{tabular}{|c|c|c|c|c|c|c|}
\hline \multirow[b]{2}{*}{ Bones } & \multicolumn{6}{|c|}{ DPH } \\
\hline & 5 & 17 & 22 & 24 & 26 & 29 \\
\hline \multicolumn{7}{|l|}{ Frontal } \\
\hline \multicolumn{7}{|l|}{ Parietal } \\
\hline \multicolumn{7}{|c|}{ Supraoccipital } \\
\hline \multicolumn{7}{|c|}{ Parasphenoid } \\
\hline \multicolumn{7}{|c|}{ Basisphenoid } \\
\hline \multicolumn{7}{|c|}{ Basioccipital } \\
\hline \multicolumn{7}{|c|}{ Premaxillary } \\
\hline \multicolumn{7}{|l|}{ Maxillary } \\
\hline \multicolumn{7}{|l|}{ Dentary } \\
\hline \multicolumn{7}{|l|}{ Articular } \\
\hline \multicolumn{7}{|l|}{ Quadrate } \\
\hline \multicolumn{7}{|c|}{ Hyomandibular } \\
\hline \multicolumn{7}{|l|}{ Ceratohyal } \\
\hline \multicolumn{7}{|l|}{ Opercle } \\
\hline \multicolumn{7}{|l|}{ Cleithrum } \\
\hline \multicolumn{7}{|c|}{ Abdominal vertebrae } \\
\hline \multicolumn{7}{|c|}{ Caudal vertebrae } \\
\hline \multicolumn{7}{|l|}{ Dorsal fin } \\
\hline \multicolumn{7}{|l|}{ Caudal fin } \\
\hline \multicolumn{7}{|l|}{ Anal fin } \\
\hline \multicolumn{7}{|l|}{ Pelvic fin } \\
\hline Pectoral fin & & & & & & \\
\hline
\end{tabular}

Fig. 5. The onset of the ossification process of clearly visible elements in group $\mathrm{S}$ (gray bars) and group C (black bars) 


\section{Discussion}

Despite the fact that the common carp is one of the oldest cultured and most domesticated fish in the world (WOHLFARTH, 1995; BAKOS and GORDA, 2001), its ontogenetic processes have not been fully elucidated, and there is a great variability and fragmentation in the data published. A possible reason for this could be the involvement of numerous insufficiently researched external (non-genetic) and internal (genetic, micro environmental) factors that modulate morphogenesis (BOGLIONE et al., 2013). According to OSSE and VAN DEN BOOGAART (1995) and MABEE et al. (2002) development of morphological structures is strongly correlated with functional requirements. This conclusion is in accordance with the results of our study.

At $5 \mathrm{DPH}$, there was no statistical difference in the values of SL between groups S and C. In both groups, the existing skeleton was made of cartilage and there was no sign of ossification. The same was previously described by ITIZAWA (1963) and PASHINE and MARATHE (1977). From 17 DPH to $26 \mathrm{DPH}$, the values of SL differed statistically between the groups (Table 1) and, importantly, a variation in the onset of ossification is present (Fig. 2). In both groups, ossification begins at 17 DPH in the parasphenoid, basisphenoid, ceratohyal and cleithrum, which could be explained by the functional requirements at this life stage (MOSHAYEDI et al., 2016). The parasphenoid and basisphenoid form the base of the cranium, give firmness to the skull, and act as an attachment site for some masticatory muscles. The ceratohyal has the main role in articulation with branchiostegal rays. The cleithrum extends from the pectoral fin and forms the posterior edge of the gill chamber. At $17 \mathrm{DPH}$, in group $\mathrm{C}$, ossification was also present in the basioccipital, premaxillary, maxillary and dentary, as well as the hyomandibular and opercle. PASHINE and MARATHE (1979) described a similar onset of ossification, but in much smaller common carp larvae (total length $7.5 \mathrm{~mm}$ ). At 22 $\mathrm{DPH}$, ossification was noticed in both groups in the articular and quadrate bones. In $\mathrm{S}$ group, it was visible in the basioccipital, premaxillary, maxillary, dentary, hyomandibular and opercle. Additionally, in $\mathrm{C}$ group ossification started in the supraoccipital.
Although the ossification sequence in the head is similar, a delay was visible in group S. At $24 \mathrm{DPH}$ the frontal and parietal started to ossify in C group, while in $\mathrm{S}$ group these two bones, as well as the supraoccipital, only showed signs of ossification at $29 \mathrm{DPH}$.

In the vertebral column, the first sign of ossification was noticed in the abdominal vertebrae at $17 \mathrm{DPH}$ in both groups. Ossification started on the outer parts of the first three vertebral bodies, and proceeded backwards. The caudal vertebrae started to ossify at $17 \mathrm{DPH}$ in group C, but at $22 \mathrm{DPH}$ in group $\mathrm{S}$. The last three caudal vertebrae and urostyle ossified first, and the ossification proceeds forward. Considering the time and onset of ossification of the vertebrae, the results of the present study do not coincide with those of ITIZAWA (1963). ITIZAWA (1963) reported that the ossification sequences of the vertebral column occur much earlier in common carp larvae (5 DPH/SL $7.0 \mathrm{~mm}$ ), and with a dissimilar pattern. The author placed special emphasis on the first three vertebral bodies that ossify only after the backwards proceeding ossification has reached the $15^{\text {th }}$ vertebra. Furthermore, ITIZAWA (1963) pointed out that the ossification sequence in the caudal region of the vertebral column is the most complicated. According to him, the whole process of vertebral column ossification is completed at $15 \mathrm{DPH}$ (SL $10.9 \mathrm{~mm}$ ). SŁOMIÑSKA and JEZIERSKA (2000) recorded the end of ossification in the vertebral column of common carp at around $40 \mathrm{DPH}$, which is 25 days later than ITIZAWA (1963) stated and 11 days later than was observed in this study.

Ossification of the fins started at $22 \mathrm{DPH}$. In both groups, the dorsal fin ossified first. Simultaneously, in group $\mathrm{C}$ ossification was also noticed in the caudal fin. In group $\mathrm{S}$ the ossification process started in the caudal fin at $24 \mathrm{DPH}$. Ossification of the anal and pectoral fins in group $\mathrm{C}$ was noticed at $24 \mathrm{DPH}$, while in S group it occurred at $26 \mathrm{DPH}$. In both groups, the pelvic fins started to ossify at 26 DPH. The same order was described by ITIZAWA (1963), but the starting point was much earlier (12 DPH/SL $9.3 \mathrm{~mm}$ ). 


\section{Conclusion}

The onset of ossification is similar in both studied common carp groups, but not completely identical. Inconsistency with data from the literature was also found. Furthermore, we confirmed that in common carp the sequence of ossification is not determined by age (DPH). Significantly, larger, fast-growing specimens ossify earlier. No trade-off between fast growth and onset of ossification was confirmed in our study.

\section{References}

ARENDT, J. D., D. S. WILSON (2000): Population differences in the onset of cranial ossification in pumpkinseed (Lepomis gibbosus), a potential cost of rapid growth. Can. J. Fish. Aquat. Sci. 57, 351-356.

DOI: $10.1139 /$ cjfas-57-2-351

BAKOS, J., S. GORDA (2001): Genetic resources of common carp at the Fish Culture Research Institute, Szarvas, Hungary. FAO, Rome.

BAEVERFJORD, G., T. ÅSGÅRD, K. D. SHEARER (1998): Development and detection of phosphorus deficiency in Atlantic salmon, Salmo salar L., parr and post-smolts. Aquacult. Nutr. 4, 1-11.

DOI: 10.1046/j.1365-2095.1998.00095.x

BERALDO, P., M. PINOSA, E. TIBALDI, B. CANAVESE (2003): Abnormalities of the operculum in gilthead sea bream (Sparus aurata): morphological description. Aquaculture 220, 89-99.

DOI: $10.1016 / \mathrm{S} 0044-8486(02) 00416-7$

BOGLIONE, C., P. GAVAIA, G. KOUMOUNDOUROS, E. GISBERT, M. MOREN, S. FONTAGNÉ, P. E. WITTEN (2013): Skeletal anomalies in reared European fish larvae and juveniles. Part 1: normal and anomalous skeletogenic processes. Aquaculture 5, 99-120.

DOI: $10.1111 /$ raq.12015

BURDI, A. M. (2010): Morphological development of the axial skeletons of Esox Lucius and Esox Masquinongy (Euteleostei: Esociforms), with comparisons in developmental and mineralization rates. Master's Theses, Loyola University Chicago, Chicago, USA.

DOI: 10.1111/j.1439-0426.2010.01421.x

DESCHAMPS, M. H., J. Y. SIRE (2010): Histomorphometrical studies of vertebral bone condition in farmed rainbow trout, Oncorhynchus mykiss. J. Appl. Ichthyol. 26, 377-380.

DOI: 10.1111/j.1439-0426.2010.01438.x

DINGERKUS, G., L. D. UHLER (1977): Enzyme clearing of alcian blue stained whole small vertebrates for demonstration of cartilage. Stain Technol. 52, 229-232.

DOI: $10.3109 / 10520297709116780$
GREGORY, T. R., C. M. WOOD (1998): Individual variation and interrelationships between swimming performance, growth rate, and feeding in juvenile rainbow trout (Oncorhynchus mykiss). Can. J. Fish. Aquat. Sci. 55, 15831590 .

DOI: $10.1139 /$ f98-044

HALVER, J. E., L. M. ASHLEY, R. R. SMITH (1969): Ascorbic acid requirements of coho salmon and rainbow trout. Trans. Amer. Fish. Soc. 4, 762-771.

DOI: 10.1577/1548-8659(1969)98[762:AAROCS]2.0.CO;2

HULATA, G. (1995): A review of genetic improvement of the common carp (Cyprinus carpio L.) and other cyprinids by crossbreeding, hybridization and selection. Aquaculture $129,143-155$.

DOI: 10.1016/0044-8486(94)00244-I

ITIZAWA, Y. (1963): The ossification sequences of the vertebral column in the carp and the snake-head fish. B. Jpn. Soc. Sci. Fish. 29, 667-674.

KAVANAGH, K. D., R. A. ALFORD (2003): Sensory and skeletal development and growth in relation to the duration of the embryonic and larval stages in damselfishes (Pomacentridae). Biol. J. Linn. Soc. 80, 187-206.

DOI: 10.1046/j.1095-8312.2003.00229.x

KUŽIR, S., I. KOUTIS, T. TRBOJEVIĆ VUKIČEVIĆ, K. MATANOVIĆ, M. BOŽIĆ, K. KURI, E. GJURČEVIĆ (2018): Growth and osteological development of two Croatian common carp (Cyprinus carpio L) strains preliminary study. Anat. Histol. Embryol. 37, 48-48.

DOI: $10.1111 /$ ahe. 12369

LI, D., C. FU, W. HU, S. ZHONG, Y. WANG, Z. ZHU (2007): Rapid growth cost in "all-fish" growth hormone gene transgenic carp: Reduced critical swimming speed. Chinese Sci. Bull. 52, 1501-1506.

DOI: $10.1007 / \mathrm{s} 11434-007-0217-x$

MABEe, P. M., P. L. CROTWELL, N. C. BIRD, A. C. BURKE (2002): Evolution of median fin modules in the axial skeleton of fishes. J. Exp. Zool. 294, 77-90.

MOSHAYEDI, F., S. EAGDERI, M. IRI (2016): Body shape change in Common carp, Cyprinus carpio var. Sazan (Teleostei: Cyprinidae), during early development using geometric morphometric method. Iran. J. Ichthyol. 3, 210-217. DOI: $10.7508 /$ iji.2016.0

OSSE, J. W. M., J. G. M VAN DEN BOOGAART (1995): Fish larvae, development, allometric growth and the aquatic environment. Ices. Mar. Sc. 201, 21-34.

PASHINE, R. G., V. B. MARATHE (1977): The development of the chondrocranium of Cyprinus carpio Linn. P. Indian Acad. Sci. B 85, 351-363.

DOI: $10.1007 / \mathrm{BF} 03052387$

PASHINE, R. G., V. B. MARATHE (1979): Observations on the ossification centres in the skull of Cyprinus carpio Linn. P. Indian Acad. Sci. B 88, 13-23. 
REIMER, T., T. DEMPSTER, A. WARGELIUS, P. GUNNAR FJELLDAL, T. HANSEN, K. A. GLOVER, M. F. SOLBERG, S. E. SWEARER (2017): Rapid growth causes abnormal vaterite formation in farmed fish otoliths. J. Exp. Biol. 220, 2965-2969.

DOI: $10.1242 /$ jeb. 148056

REINBOLD, D., G. H. THORGAARD, P. A. CARTER (2009): Reduced swimming performance and increased growth in domesticated rainbow trout, Oncorhynchus mykiss. Can. J. Fish. Aquat. Sci. 66, 1025-1032.

DOI: 10.1139/F09-064
ROJO, A. L. (1991): Dictionary of Evolutionary Fish Osteology. CRC Press, Inc. Boca Raton, Florida, USA.

SŁOMIÑSKA, I., B. JEZIERSKA (2000): The effect of heavy metals on postembryonic development of common carp, Cyprinus carpio L. Arch. Ryb. Pol. 8, 119-128.

WOHLFARTH, G. W. (1995): The common carp and Chinese carps. In: Conservation of Fish and Shellfish Resources: Managing Diversity. (Thorpe, J., G. Gall, J. Lannan, C. Nash, Eds.), Academic Press, London, San Diego, New York, Boston, Sydney, Tokyo, Toronto, pp. 138-176.

DOI: 10.1016/b978-012690685-1/50010-2

KUŽIR, S., K. DRAŠNER, K. MATANOVIĆ, L. BASTIANČIĆ, I. VLAHEK, S. SAVOCA, E. GJURČEVIĆ: Odnos brzine rasta i procesa okoštavanja u šarana (Cyprinus carpio). Vet. arhiv 90, 485-492, 2020.

\section{SAŽETAK}

Odnos između brzine rasta i procesa okoštavanja u riba nije ujednačen. U nekih vrsta te su vrijednosti u pozitivnoj korelaciji, dok je u drugih vrsta prisutan svojevrsni kompromis (engl. trade-off), brži rast negativno utječe na proces okoštavanja. Cilj ovog istraživanja je provjeriti hipotezu o postojanju negativne korelacije između brzine rasta i procesa okoštavanja u šarana (Cyprinus carpio). U tu svrhu, jedinke šarana podrijetlom iz dvije skupine s različitom brzinom rasta (ukupno 96 jedinki) uzorkovane su između 5. i 29. dana nakon valjenja. Mjerena je standardna dužina i prikazana u korelaciji s brojem dana poslije valjenja. U svrhu procjene razvoja koštanog sustava, uzorci su fiksirani u 10\% neutralnom formalinu i obojeni metodom za prikaz kosti i hrskavice. Poseban naglasak stavljen je na proces okoštavanja u jasno vidljivim kostima glave, kralježnice i peraja. Prema rezultatima našeg istraživanja, u brzorastućih jedinki proces okoštavanja je nastupio ranije. U ovom radu opovrgnuta je hipoteza o postojanju negativne korelacije između brzine rasta i procesa okoštavanja.

Ključne riječi: trade-off; brzina rasta; okoštavanje; šaran 